religious observances. The far larger number of institutions, however, occupy a position intermediate between this positive, thorough-going denominationalism and unsectarianism; and the objection brought against such is that their position is doubtful and uncertain, and their ambiguity a positive evil. The advantage of the unsectarian school, such as Harvard, is that its position is unmistakable, and a voluntary activity in religious matters is stimulated, while no attack is made on the student's faith. The officers and teachers are appointed without reference to denomination, and students are free to go to church or not. It has the disadvantage of not possessing the entire support of any denomination, and hence suffers a loss of power. It appears to be indifferent to religion, though in reality it is not. On the other hand, Dr. McCosh argued that morality could not be taught effectively in an institution without the aid of religion; that when religion is not honored in a college, agnosticism will prevail among the students; that religion gives higher aims and nobler ambitions, while its absence destroys zeal and activity. He also held that the period of college life was that in wbich moral and religious guidance was most needed. He knew that it was possible to retain a lively interest in religion without sacrifice of tolerance and religious freedom.

\section{THE EXTENSION OF COPYRIGHT.}

THE eighth clause of the eighth section of the constitution of the United States grants to congress the power "to promote the progress of science and useful arts, by securing for limited times to authors and inventors the exclusive right to their respective writings and discoveries." The effort now making to revise the copyright law looks to an enlargement of the operation of this clause. Heretofore, by ' authors' the law has meant only 'citizens of the United States, or residents therein.' It is now proposed in effect to strike out this limitation, and give 'exclusive right' ' for limited times' to all authors who may comply with the conditions of the statute pertaining to copyright.

At a recent hearing before the senate committee on patents, I offered what seemed to me the simplest, most direct, and most reasonable practical solution of the problems involved in international copyright, and a careful consideration of all the plans proposed has only confirmed my confidence in the method which I outlined. This method supposes the present law, now applicable to citizens of the United States only, to be extended to any alien who will accept the conditions under which an American author lives. The American author must enter the title of his book in the office of the librarian of congress; he must publish his book in this country, recording upon every copy the fact that he has taken out copyright; and within ten days of publication he must deposit two copies of his book in the library of congress. Then only is his title in his literary property complete.

I would ask nothing more and nothing less of the foreigner. I would require him to record his title, to publish his book here, and to deposit his two copies in the library of congress within ten days of publication, and then I would give him all the protection which the law gives to the American author. No one should be allowed to print his book except his own agent, and no copies from other countries should be allowed to come in to interfere with the edition copyrighted and published here.

Probably none of the advocates of international copyright would seriously object to this method as regards the entry of the title and the deposit of the two copies. There are some, however, who claim that the foreigner shall not have imposed upon him the condition which rests upon the native author, of publication in this country. Why not? It is said that we have been unjust to the foreign author, and that now this injustice is working the greater injury to the American author. It is to repair the wrong that we now propose an amendment of the statute. The only rational reparation is one which will put the two authors on an equality. We ask that the English author shall accept the conditions of the American author in America. We are perfectly willing to concede that the American author shall submit to the conditions of the English author in England.

This solution of the copyright problem is not more based upon theoretical fitness than it is upon practical experience. In the absence of any international legal arrangement, there has grown up of late years, between England and America, an international business arrangement. An American author to-day may secure protection for his book in England by publishing there twenty-four hours earlier than he publishes in this country. An English author may secure a quasi protection for his book on this side by publishing here at the same time as he publishes in his own country. The distinction in the two cases must be noticed. By English custom, fortified, I think, by a decision of a minor court, an American author's book which has appeared in England a day earlier than in the author's coun- 
try, is so far protected that no other publisher than the one with whom the author has arranged can bring it out. There is no such law, nor even any such custom, in this country. But so great an advantage has an American publisher over his competitors, when by previous arrangement he is enabled to bring out an American edition of an English book simultaneously with its appearance abroad, that he rarely hesitates to take the risk, and he pays the English author or his representative well for this advantage of simultaneous publication.

Now, what the Englishman is doing for us under cover of a strong custom, and so far undisputed law, let us do for him under sanction of a statute; and the problem is so far solved that we may safely leave all petty details to be adjusted by the laws of trade between the two countries, and the interests of the parties chiefly concerned. Simultaneous publication, then, in the two countries, is the fairest way out of our difficulties. It is so far compulsory that it makes the best foreign thought as immediately available in America as in Europe. It compels the publisher and author not to suit their own convenience, but to study the demands of two continents; and 'the progress of science' will receive by such a course an impetus which no method, planned for the advantage of the author alone, or the publisher alone, or the people alone, can possibly give.

\section{H. E. SCUDDER.}

\section{INTERNATIONAL COPYRIGHT.}

"THE question of copyright, like most questions of civil prudence, is neither black nor white, but gray." So said Mr. Macaulay. Mr. Lowell says it is a question of robbery; the American copyright league, a question of piracy. Those who use these epithets base their assertions upon the ground that an author has a broader, more extensive right of property in his publications than in other property. That a man has property in the production of his brain which ought to be protected is admitted; but tae extent of that protection must depend upon the public interest.

Scruton, in his book entitled ' Laws of literary property,' published in 1883 in London, says, " Utilitarianism is the groundwork of the science and art of legislation, and therefore the reason which justifies the enactment of any particular law is the ultimate benefit to result to the community from its conformity to such a law." This claim of property in books, as made by Mr. Lowell and the league, is of modern origin, and was not made until the early part of the last century, long after the introduction of printing, and is not recog- nized by any civilized government. Grants in the nature of copyright were first made to printers, to encourage the multiplication of books, and were subsequently made for the benefit of the authors. In England the courts have decided that, at common law, an author had no right of property in his publications, and that whatever rights he has have been created by statute law.

Our constitution provides that congress shall have power "to promote science and the useful arts by securing for limited times to authors and inventors the exclusive right to their respective writings and discoveries." The powers of congress are more limited than those of the parliament of Great Britain, which are not restricted by any constitution; and many grants which in England have been made 'for the benefit of authors,' would in this country have been unconstitutional. Every copyright is a monopoly. This proposition has been admitted by some of our authors, but denied by others who were probably ignorant of the meaning of the word. A monopoly is ' an exclusive trading privilege :' it is " the sole right or power of selling something ; the full command over the sale of any thing; a grant from the sovereign to some one individual, of the sole right of making and selling some one commodity."

Every monopoly must be construed strictly, and should not be extended where reasonable doubt exists against the right. If authors limited their claims of property in the productions of their brains to the manuscript or a printed copy, no one would dispute their right to hold or lease or sell it ; but they claim much more, - the monopoly of publication and selling, the exclusive right of multiplying copies everywhere and in every tongue and for all time, and they appeal to the government for aid in enforcing this right. Every nation has repudiated this claim as contrary to the interests of the public, and granted only such limited rights as it judged expedient.

General Hawley, who introduced the bill favored by the league, which gave the foreign author permission to publish abroad or in this country, realizing the weight of the objections made by the publisher and printer, that it would result in transferring the printing of all international copyrighted books to foreign countries, proposed an amendment to his bill, providing that every foreign book copyrighted in this country should be printed and published here. If the view of the league is correct, this amendment robs the foreign author of a part of his property by depriving him of the privilege of selecting the time or place of publication, or choosing his publisher. The tendency of this amendment would be to increase the cost of copyrighted books, 